Macbeth, W.A.A.G. \& Riddle, P.R. (1964) Gas filled abscess cavity as a manifestation of diverticulitis of the colon. British Journal of Radiology, 37, 861 .

Marano, A.J., Bell, A.L.L., BegG, C.F. \& Fitzpatrick, H.F. (1964) Giant diverticulum of the sigmoid colon. Journal of the American Medical Association, 188, 608.

Melamed, M. \& Pantone, A. (1960) Giant diverticula of the colon. Archives of Surgery, 81, 723.

Moore, J.A. \& Gold, C. (1964) Giant diverticulum of sigmoid colon. British Journal of Surgery, 51, 876.
Retterbush, W.C., Fishman, M.B., Baird, W.A. \& Collins, J.I. (1951) Emphysematous cholecystitis. Report of case with successful treatment. Annals of Surgery, 134, 268.

Silberman, E.L. \& ThORNer, M.C. (1961) Volvulus of giant sigmoidal diverticulum. Journal of the American Medical Association, 177, 782.

Smaltino, F., Gauieri, A. \& Del Vecchio, E. (1967) Su un raro caso di diverticolo solitario gigante del sigma. Giornale Italiano di Chirurgia, 23, 971.

\title{
Primary pneumococcal peritonitis in the nephrotic syndrome
}

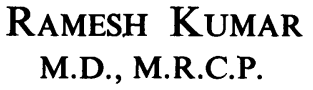

\author{
M. G. McGeOWN \\ M.D., Ph.D., F.R.C.P.(Ed.)
}

\author{
J. McEvoy \\ M.D., M.R.C.P.
}

Renal Unit, Belfast City Hospital, Belfast, BT9 7 AB

Primary pneumococcal peritonitis appears to have been a frequently seen presenting feature of the nephrotic syndrome in children prior to the advent of antimicrobial therapy (Barnett \& Shibuya, 1954; Fowler, 1957).

The present report is of a case of primary pneumococcal peritonitis in a boy who was thought to have acute appendicitis and underwent a laparotomy.

\section{Case report}

An 11-year-old boy presented with the complaints of vomiting and abdominal pain of 2 days' duration. Prior to the onset of these symptoms, his parents noticed some puffiness of the face and found the boy rather listless and tired. First, he began vomiting frequently and complained of pain in his abdomen. This pain was constant and aggravated by movement. There was no preceding history of sore throat, pyoderma or chest infection. He had no haematuria, arthralgia, headaches or convulsions. On admission, he had not passed urine for about $18 \mathrm{hr}$.

On clinical examination, his temperature was $101^{\circ} \mathrm{F}$, his eyes were puffy and had slight pretibial oedema. He looked toxic and had an erythematous rash on his neck and upper part of the chest and a few erythematous spots on his buttocks. His heart was regular at $140 / \mathrm{min}$; and blood pressure was $125 / 70$ $\mathrm{mmHg}$. The examination of the abdomen revealed generalized tenderness, most marked in the right iliac fossa with muscle guarding and rebound tenderness.

Correspondence: Dr Ramesh Kumar, Registrar, Renal Unit, Belfast City Hospital, Belfast, BT9 7AB.
His bladder was palpable midway between the $\varnothing$ symphysis pubis and the umbilicus, and on catheterization the urine showed marked proteinuria. His chest was clear and there was no neurological abnormality. A diagnosis of acute peritonitis with nephrotic syndrome was made, but with localized tenderness in the right iliac fossa and muscle guarding, acute appendicitis with perforation could not be excluded.

On the day of admission a laparotomy was performed through a long right paramedian incision and 2 pints of thin, milky fluid was aspirated and the pelvic sediment of the peritoneal fluid showed marked fibrinous streaking. His appendix and other organs in the abdominal cavity were normal except for marked enlargement of mesenteric, para-aortic and iliac lymph nodes. The peritoneal cavity was cleaned out and a biopsy of a mesenteric gland was taken, which on histological examination showed 'reactive hyperplasia'.

His haemoglobin was $14.1 \mathrm{~g} / 100 \mathrm{ml}$; WBC $18,200 / \mathrm{mm}^{3}$ with $80 \%$ polymorphonuclear cells and an ESR of $85 \mathrm{~mm} / \mathrm{hr}$. Urinalysis showed specific gravity 1030 ; protein +++ , a few erythrocytes, and granular casts, culture was sterile. His blood urea was $43 \mathrm{mg} / 100 \mathrm{ml}$ and plasma electrolytes were normal. Both peritoneal fluid and a swab from the peritoneal cavity grew pneumococci profusely on culture. Blood cultures were sterile. His throat swab did not grow streptococci and the anti-streptolysin 0 titre was 160 units $/ \mathrm{ml}$. The plasma proteins were total $4.1 \mathrm{~g} / 100 \mathrm{ml}$, albumin $1.2 \mathrm{~g} / 100 \mathrm{ml}$ and on electrophoresis there was increase in alpha ${ }_{2}$-globulin 
and decreased albumin and gamma-globulin. His total urinary protein excretion was $7 \cdot 3 \mathrm{~g} / 24 \mathrm{hr}$; serum creatinine $0.6 \mathrm{mg} / 100 \mathrm{ml}$ and creatinine clearance was $63 \mathrm{ml} / \mathrm{min}$. The index of selectivity (IgG/ Transferrin clearance) was 0.06 .

During the postoperative period, he was given a course of ampicillin. This period was largely uneventful and he made a good recovery. In the initial period his daily urine output was between 500 and $800 \mathrm{ml}$ but this gradually improved with disappearance of the peripheral oedema after small doses of chlorthalidone.

On the basis of the selective proteinuria and his age, nephrotic syndrome was almost certainly due to minimal change glomerulonephritis. This was later confirmed by renal biopsy, which on light microscopy showed normal glomeruli and on electron microscopy typical foot-process changes. The patient was given a course of steroid treatment. $\mathrm{He}$ has responded fully to steroids and there has been no evidence of relapse in 4 months since the treatment was discontinued.

\section{Discussion}

Primary bacterial peritonitis is well known in children (Ladd, Botsford \& Curnen, 1939; Barnett \& Shibuya, 1954). The relationship of primary pneumococcal peritonitis and 'nephrosis' has frequently been documented in the older literature but reports are seen infrequently since the era of antibacterial therapy began. It occurs more commonly in girls than in boys (Fowler, 1957) and it is interesting to note that the above mentioned patient was a male. The cause of relationship of primary pneumococcal peritonitis and 'nephrosis' is still obscure but it has been suggested that the increased incidence among girls may be due to ascending infection in the vaginal tract.

The onset of nephrotic syndrome following pneumococcal pneumonia (Seegal, 1935) and pyoderma (Kaplan et al., 1970) has also been described but the true incidence of primary pneumococcal peritonitis in nephrotic syndrome is not known. Further, it is interesting to note that in the report of 188 cases of nephritis in children described by Gachet (1941) only one case presented with suppurative peritonitis on autopsy. In the outbreak of eighty-nine cases of nephritis in Northamptonshire described by Pleydell (1958) there were no cases of primary peritonitis. It is suggested that in the presence of abdominal pain in the nephrotic syndrome the possibility of primary peritonitis should be considered.

\section{References}

Barnett, H.L. \& Shibuya, Madoka (1954) Nephrosis in children. Postgraduate Medicine, 15, 362.

Fowler, R. (1957) Primary peritonitis. Australian and New Zealand Journal of Surgery, 26, 204.

GACHET, F.S. (1941) Course and prognosis of hemorrhagic nephritis in children. American Journal of Diseases of Children, 61, 1175.

Kaplan, E.L., Anthony, D.F., Chapman, S.S. \& Wannas MAKER, L.W. (1970) Epidemic acute glomerulonephritiassociated with Type 49 streptococcal pyoderma. I. Clinical and laboratory findings. American Journal of Medicine, 48, 9.

LADD, W.E., Botsford, T.W. \& CuRnen, E.C. (1939) Primary peritonitis in infants and children. Journal of the American Medical Association, 113, 1455.

Pleydell, M.J. (1958) An outbreak of nephritis in Northamptonshire. British Medical Journal, 2, 1382.

SEEGAL, D. (1935) Acute glomerulonephritis following pneumococcic lobar pneumonia. Archives of Internal Medicine, 56, 912. 